\title{
GYPSUM KARST OF ZAGROS MOUNTAINS (I.R. IRAN)
}

\author{
KRAS V SADRI V GOROVJU ZAGROS (I.R. IRAN)
}

FRANCO CUCCHI ${ }^{1} \&$ LUCA ZINI ${ }^{1}$

${ }^{1}$ Dipartimento di Scienze Geologiche, Ambientali e Marine dell'Università degli Studi di Trieste, TRIESTE, ITALIA

Prejeto / received: 13. 11. 2002 
Abstract

UDC: 552.53:551.44(55)

\section{Franco Cucchi \& Luca Zini: Gypsum karst of Zagros Mountains (I.R. Iran)}

Evaporite morphologies have attracted our attention during geological surveys on the Karkheh River, a water course that intersect the chain of the Mountains Zagros in the western Iran. We recognised three types of karst in the evaporitic Gachsaran Formation as a function of the localisation along the syncline axis or along a fold side. There are sinkholes and suffosion dolines or caves and collapse dolines along the syncline axis, gently dipping galleries at the contact between limestone and gypsum following maximum dip.

Key words: evaporites, tectonics, gypsum karst, Zagros Mts., Iran.

Izvleček

UDK: 552.53:551.44(55)

\section{Franco Cucchi \& Luca Zini: Kras v sadri v gorovju Zagros (I.R. Iran)}

Ob geoloških raziskavah vzdolž reke Karkheh, ki prereže gorsko verigo Zagrosa v zahodnem Iranu, je pritegnila pozornost avtorjev morfologija na evaporitih. V evaporitni formaciji Gachsaran so ločili tri tipe krasa, glede na njihovo lego vzdolž sinklinalne osi ali vzdolž krila gube. Vzdolž sinklinalne osi so vrtače, sufozijske vrtače, jame in udorne vrtače ter zmerno se spuščajoči jamski rovi na stiku apnenca in sadre, ki sledijo največjemu vpadu.

Ključne besede: evaporiti, tektonika, kras v sadri, gorovje Zagros, Iran. 


\section{INTRODUCTION}

Wonderful evaporite morphologies have attracted our attention during the geological and hydrogeological surveys for the feasibility studies of dams on the Karkheh River, a water course that intersects the chain of the Mountains Zagros in the western Iran ${ }^{1}$.

Hereafter the manifestation of hyperkarst developed in gypsum (the Gachsaran Formation Early Miocene) and conditioned at the base by limestones (the Asmari Formation - Oligocene to Miocene) are synthetically illustrated ${ }^{2}$.

\section{GEOMORPHOLOGY}

The Zagros Mountains form a relief chain stretched towards northnortheast-southsouthwest in the south-western Iran near the border with Iraq (Fig. 1). They are not excessively high surveys and from a geomorphological point of view they are the classic example of a morphostructural fold style with breached antiform and synform valleys. The fluvial network is obviously trellisshaped or better diaclinal. The water courses that normally flow along the flood axis abruptly deviate, thus cutting the ridges with gorges ${ }^{3}$ (Fig. 2.).

\section{GEOLOGY}

In the tract studied, in the core of the syncline there are evaporitic deposits of the Gachsaran Formation that overhang the limestone of the Asmari Formation. The latter form the sides of the valley and of the relief.

In detail the following geological units recognised are listed hereafter from the youngest to the oldest:

Alluvial deposits, extending all along the river course and emerging from the water across a variable width as a function of the season. They consist of sand and gravel, with a minor amount of fines and scattered boulders. They can develop as far as $5 \mathrm{~m}$ above the present river channel, being constituted in these cases almost exclusively by sand.

1 There are surveys inserted in the project of dams for hydroelectrical aims carried out by the ELECTROCONSULT of Milan in collaboration with MAHAB GHODSS Consulting Engineers of Teheran on behalf of the Ministry of Energy of the Islamic Republic of Iran. We thank the two companies for their availability.

${ }^{2}$ Franco Cucchi has carried out the field surveys and has discussed with Luca Zini the morphogenesis and the development of landforms. The text is written by 2 people and Luca Zini in particular has carried out the iconographic part.

${ }^{3}$ In Oberlander (1986) there is the description of the development of this area, result of water courses developed in correspondence of erodible cores of anticlines in relative uplifting. The fluvial segments developed as links among the orthocline tracts that today are embedded in calcareous gorges (see Fig. 2 taken from Bartolini, 1992). 
Residual soil, usually occurring in the plateau bordering the gorge in a negligible amount. It has been mapped as a separate unit only in some narrow strips in the left and right abutment, where at any rate its thickness is expected not to exceed $3 \mathrm{~m}$.

The Gachsaran Formation, outcropping in correspondence of the axis of a syncline, consists of medium bedded marlstone and gypsum in an approximate ratio of 1:2. Marlstone is brown to olive grey, fairly weak and it usually contains clasts of gypsum. Gypsum is whitish to grey, crystalline and strong. The unit is strongly affected by karst phenomena.

The Upper Asmari Formation, outcropping in the upper part of the gorge and in the adjoining plateau, consists of medium bedded to massive, light to medium grey limestone and marly limestone locally dolomitized with a few marlstone interbeds and has a thickness of about $110 \mathrm{~m}$. Some clastic layers are included within the unit: in particular, one $4 \mathrm{~m}$ thick level of conglomerate and breccia, believed to be of intraformational origin, develops close to the contact with the underlying Middle Asmari Formation. Epigean karst landforms, which are solution features derived from surface water circulation, are strongly developed, being concentrated in the bottom portion of the thick to massive beds.

From a structural point of view the studied area is located in the northeast limb of the Kabir Kuh anticline, a major structure that extends over a length of some $200 \mathrm{~km}$. The axis of the anticline passes about $10 \mathrm{~km}$ to the southwest of the investigated sector.

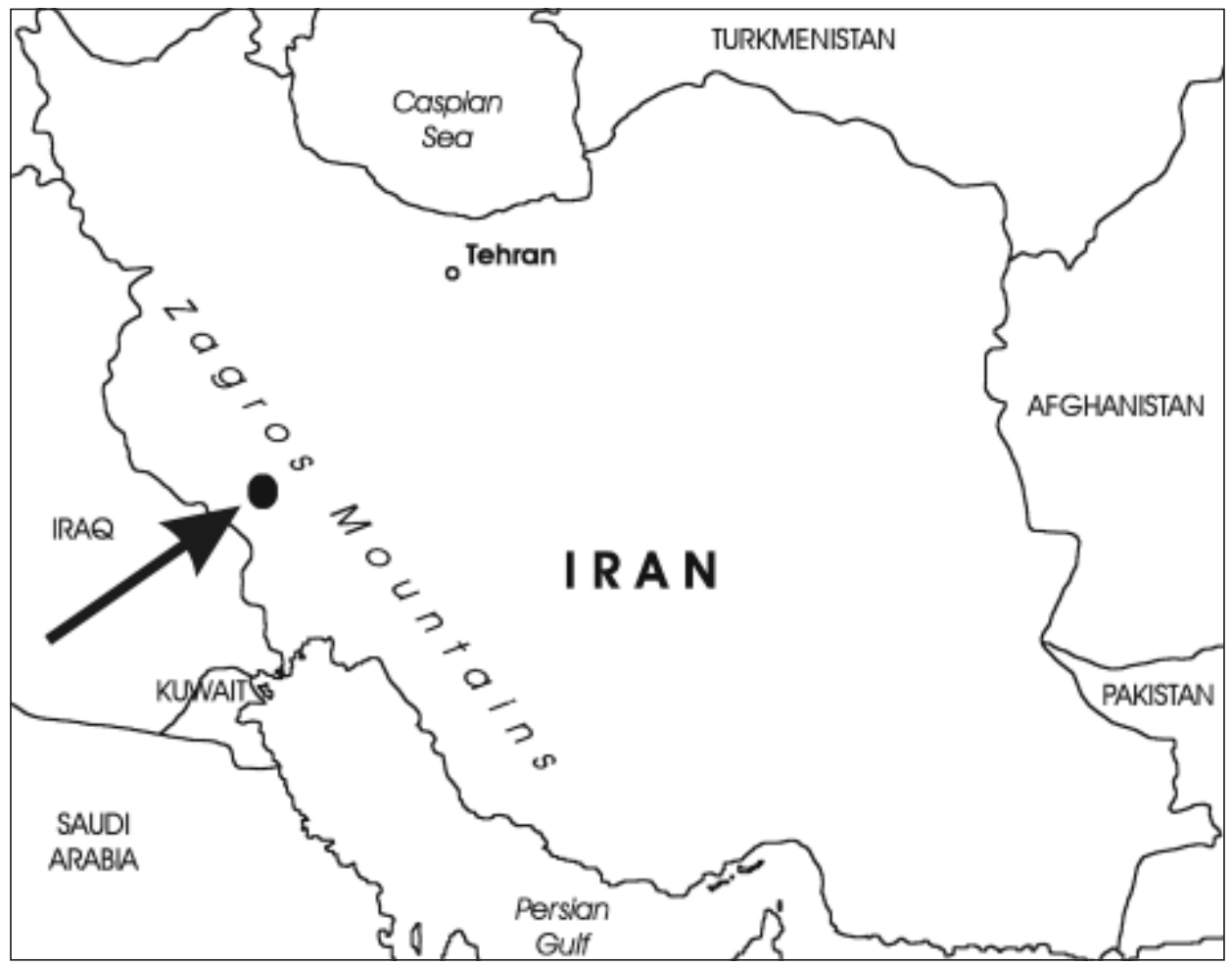

Fig. 1: Location of the area. 


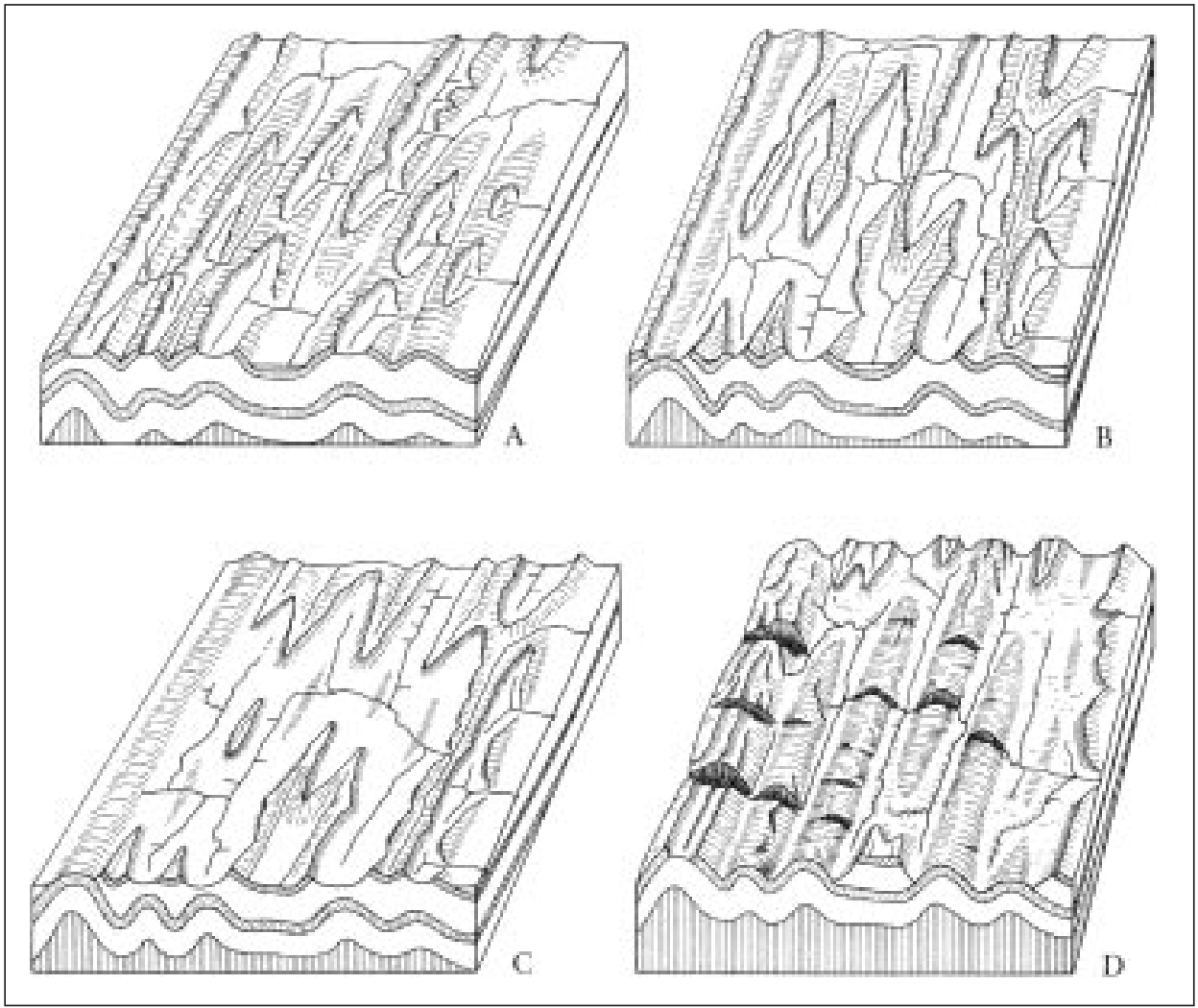

Fig. 2: Geomorphologic evolution according to Oberlander (1986); illustration taken from Bartolini (1992).

In the area the Asmari beds usually dip to the northeast with a dip angle averaging $7^{\circ}$ and ranging between $3^{\circ}$ and $10^{\circ}$. Locally, in particular in the central part of the area, the dip can turn anticlockwise and take a northnortheast or even north direction. In the southern sector a gentle anticline, with axis parallel to that of the Kabir Kuh anticline and limited extent, has been identified.

The beds attitude in the Gachsaran Formation is much more irregular, in relation with the plastic nature of the products. Here beds tend to dip more steeply and sharp strike variations are locally observed.

Numerous tectonic features have been recognised in the course of mapping, in particular along the gorge, where the whole sequence outcrops, allowing for a clearer identification of eventual disturbances. These features basically consist of faults of seemingly limited lateral extent, with vertical displacement included between 1 and $15 \mathrm{~m}$ and a sub-vertical dip angle. In several instances faults accompanied by a 1 to $5 \mathrm{~m}$ wide shear zone expressed by brecciation, by slickensides and by morphologic depressions. 
No clearly predominant fault systems exist in the area. On a statistical basis the prevailing directions are from northnortheast-southsouthwest to north-south, although the westsouthwesteastnortheast to west-east directions are not uncommon. As a general rule, the north-south / northnortheast-southsouthwest faults have a larger lateral extension and are often clearly recognisable in aerial photos.

A special attention was paid on the definition of the contact between the Upper Asmari and Gachsaran Formations, due to its influence on the deep groundwater circulation. Wherever visible, this contact is expressed by a sharp topographical break, whereby the Asmari products form planar surfaces, while the Gachsaran ones take the appearance of rolling hills.

\section{HYDROGEOLOGY}

The underground investigations performed to date have been mostly directed towards a definition of the configuration of the contact between the Asmari and Gachsaran Formations and towards a study of the lithological and hydrogeological characteristics of this contact zone.

More karst, surface or hypogean morphotypes have been recognised, among which karren in limestone and gypsum, kamenitza in limestones, sinkholes (small dolines) in limestones and gypsum, cavities in gypsum and tumulus in gypsum.

With reference to the Asmari Formation, it is affected in a variable degree by epigean karstification, basically expressed by rock shelters, open interbeds, karren and kamenitza, strictly controlled in their distribution by bedding and hence by lithology.

Voids of rounded to oval shape and with size normally included between 2 and $20 \mathrm{~cm}$ tend to be aligned along the bedding. These features are deemed to have a syndiagenetic origin and as such to extend throughout the rock mass with only partial intercommunication: when exposed to surface they have often been enlarged by dissolution.

From surface observation, the development of hypogean karst in the Asmari Formation does not seem to be intense. A few sub horizontal caves were recognised with a length of at least $15 \mathrm{~m}$ : these caves tend to narrow proceeding inside the rock mass and no evidence of significant recent water circulation within them was seen. Similarly, the interbed openings appear to tend to close penetrating a few tens of meters within the rock mass.

A sharply different hydrogeological situation was encountered in the Gachsaran Formation, where the presence of highly soluble gypsum, making up about two thirds of the stratigraphic sequence, renders the rock strongly karstification prone.

\section{KARST}

The following karst features were recognised in the outcrops of the Gachsaran Formation:

Caves: with a length of tens of meters and width and height of up to $8 \mathrm{~m}$, have a subhorizontal extension and their bottom is often covered by loose deposits, while their roof can be modified due to gravitational collapses. Caves may act as temporary swalow-holes or may occasionally be interested by the surface drainage. 
Sinkholes: with a diameter of 0.5-5 m, have a mainly sub vertical extension, can occur either in rock or in non consolidated deposits and derive from collapse of some underground cavity.

Dolines: have a mode of formation similar to that of the sinkholes, from which they are differentiated for their larger size, with a diameter more than $5 \mathrm{~m}$ and reaching as much as $250 \mathrm{~m}$.

Two types of dolines are recognised: the suffosion dolines and the collapse dolines. The first ones open in alluvial deposits on the bottom of the valleys and they are due to the dissolution of gypsum upon which they are placed.

The second one have steep sides and in places they cover with slides the galleries which roof collapse has formed the depression.

Swalow-holes: they have a mainly sub-vertical extension, similarly to the sinkholes, from which they are differentiated for the evidence of temporary water courses disappearing within them.

Swalow-holes and caves can be located at the end of blind valleys.

As shown in figures 3-10, these karst features are widespread throughout the area, being especially developed around the contact between the Asmari and Gachsaran Formations. Karst extends well beyond the area, in particular eastward, towards the northeast border of the syncline: here the Gachsaran beds can have a steep attitude due to microfolding and sub vertical swalow-holes, formed in soluble beds included between not karst prone horizons, and they are very common.

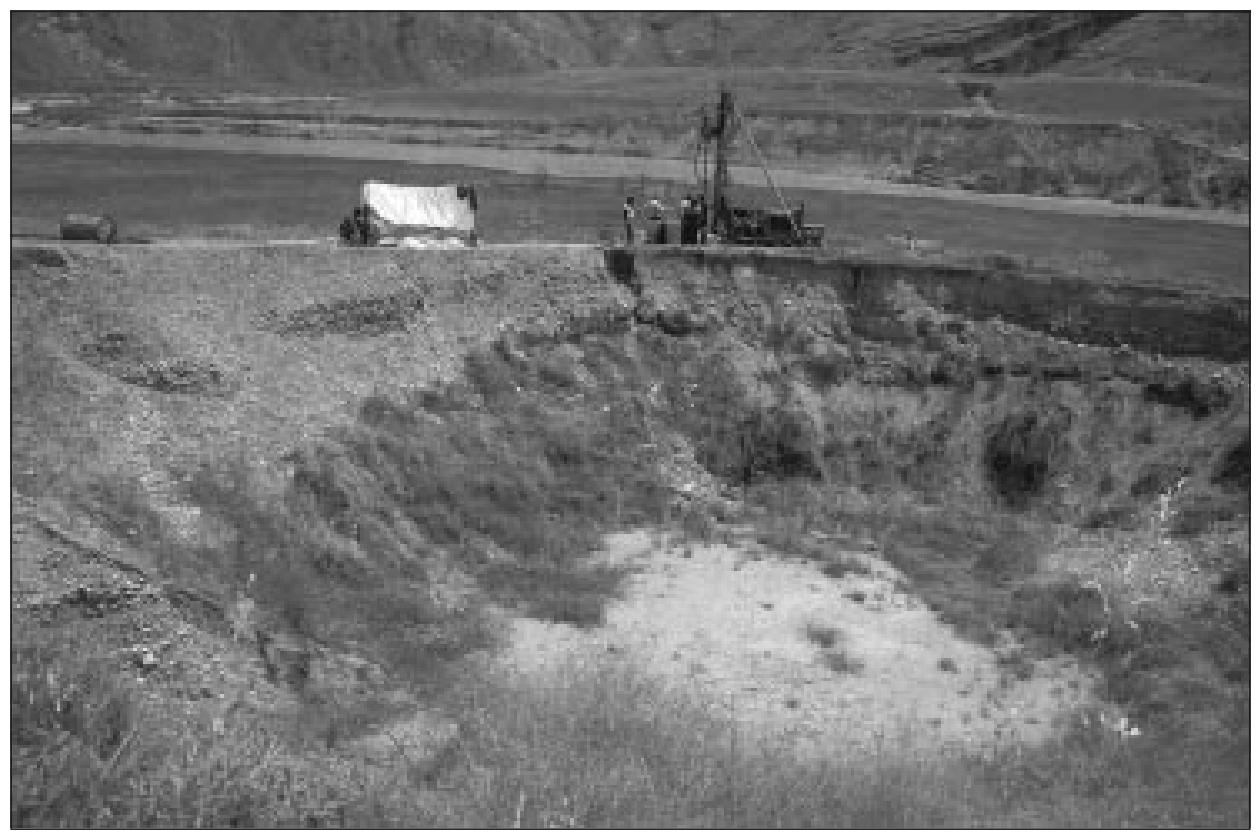

Fig. 3: Alluvial doline near the Karkheh River. 


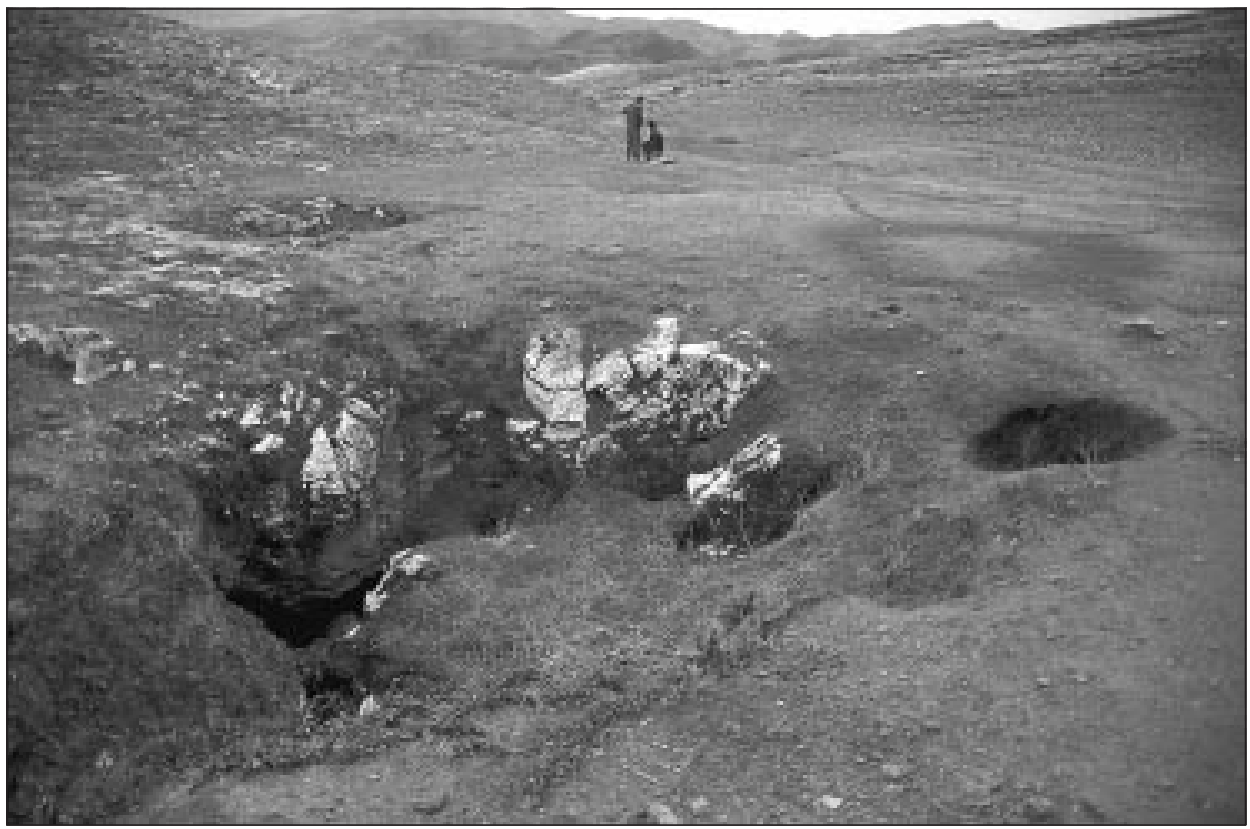

Fig. 4: Sinkhole opening in residual soils.

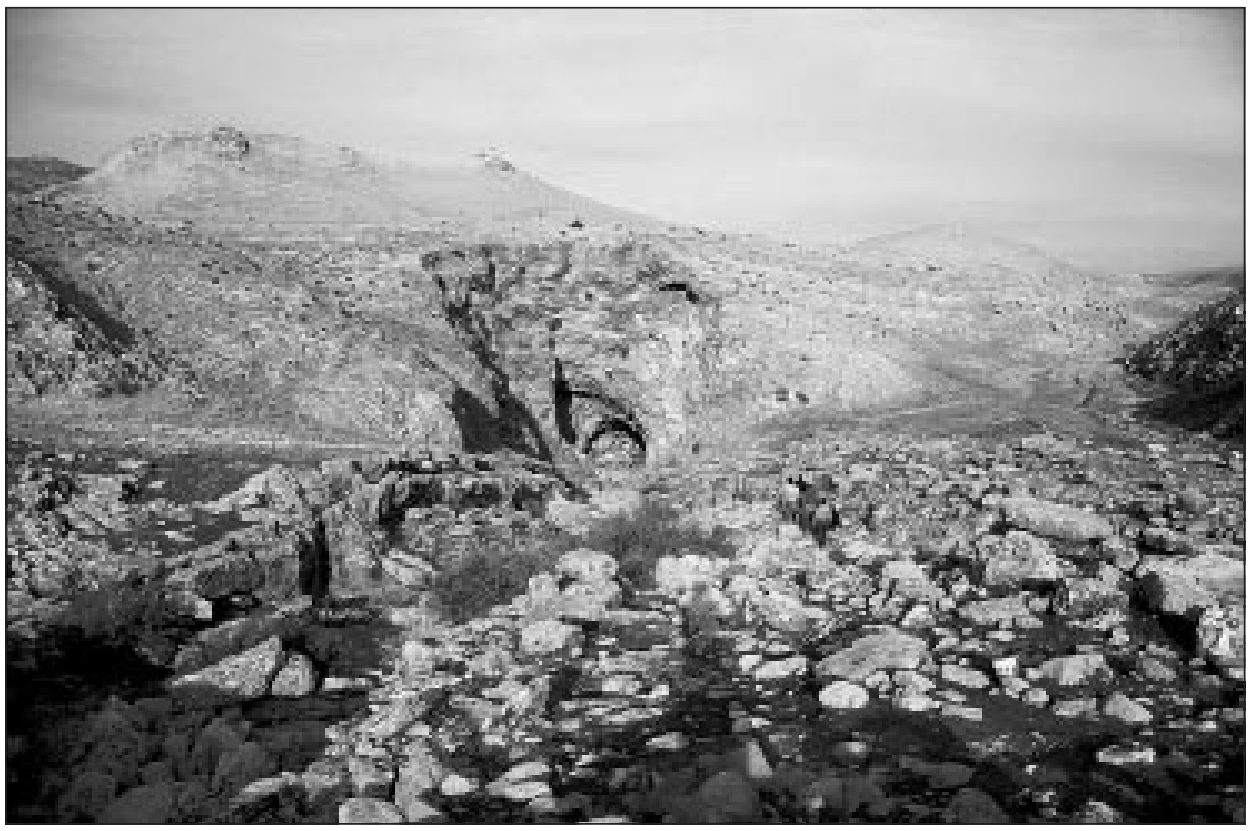

Fig. 5: Cave working as swalow-hole. At the top of limestone a little gully conveys the waters in the cavity whose entrance, made up of gypsum, is modified by collapses. 


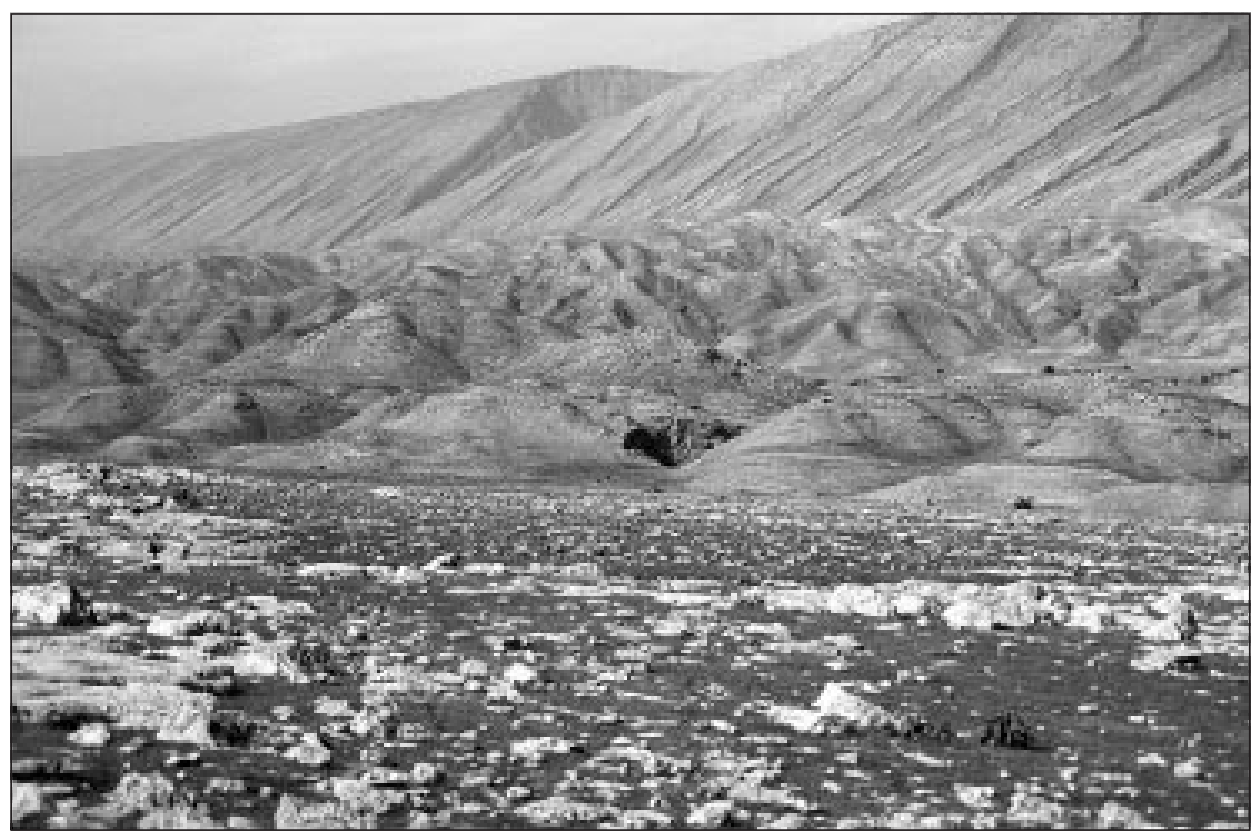

Fig. 6: Sinkhole and cave at the contact between limestone and gypsum. Gypsum must be observed along the syncline axis and the calcareous antiform relief.

\section{DISCUSSION}

The distribution of the karst features appears to be controlled by a combination of stratigraphic and structural factors. As regards stratigraphy, the presence of thick and continuous layers of gypsum obviously enhances the possibility of karstification: one of these layers occurs right at the contact with the Asmari Formation and is, in fact, highly karstified. As regards structure, the occurrence of open faults or fractures, by facilitating the infiltration of meteoric water, can trigger phenomena of dissolution which would eventually bring to the formation of caves, sinkholes or swalow-holes. One alignment of caves and sinkholes observed to the east of the dam axis is clearly controlled by an east-west lineation, while other alignments might be controlled by northwest-southeast fractures.

The existence of intense hypogean karstification in the Gachsaran Formation was confirmed by the boreholes drilled to investigate the contact with the Asmari Formation. This karstification is expressed either by cavities (detected during drilling operation by sudden drops of the rods string) or by loose material within the rock mass (usually clay and gravel), interpreted as being the infilling of previous cavities.

Karstification is usually restricted to the upper 30 to $40 \mathrm{~m}$ below ground level. At the contact with the Asmari Formation, a thick pure gypsum layer intersected in boreholes at depths of 50 to $150 \mathrm{~m}$ did not show any evidence of karst, in contrary to the appearance of the same level at surface. 


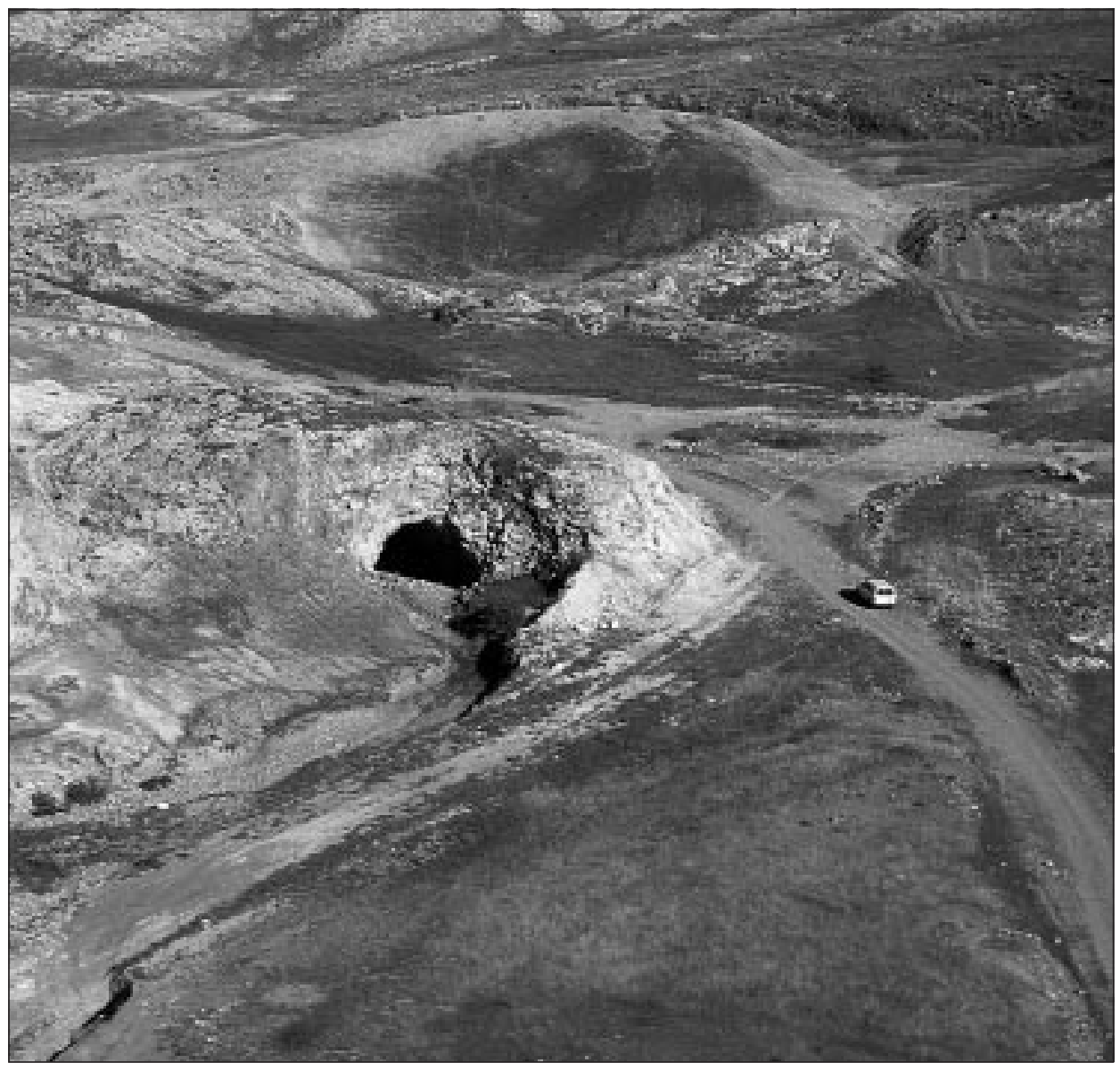

Fig. 7: Gently dipping gallery at the contact between limestone and gypsum following maximum dip.

Beds exhibit commonly lateral variations, in agreement with the mode of deposition of the unit in a shallow evaporitic environment.

Except for the levels associated with cavities, where no pressure could be reached, the Lugeon tests indicated a low to very low permeability both within the gypsum and marlstone interlayers.

The data of drilling, combined with the surface observations on both the Asmari and Gachsaran Formations, allow the groundwater circulation scheme in the area to be reconstructed on a preliminary basis (Fig. 11).

The meteoric water precipitating on the Asmari products partly runs off to feed the surface drainage and partly infiltrates into the ground, slowly percolating through joints and fissures to recharge the main aquifer. No springs are known to emerge in the neighbourhood from the Asmari 
Franco Cucchi \& Luca Zini: Gypsum karst of Zagros Mountains (I.R. Iran)

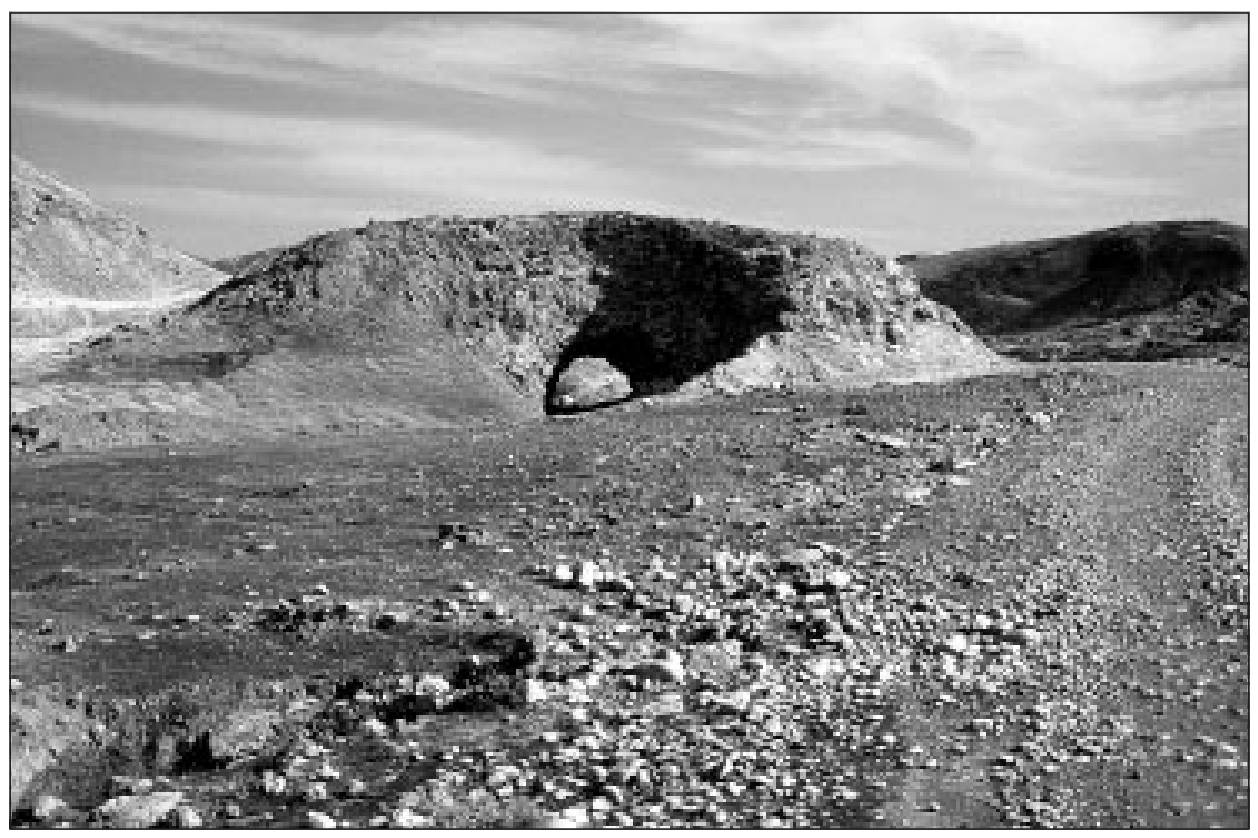

Fig. 8: Residual gallery at the contact between limestone and gypsum.

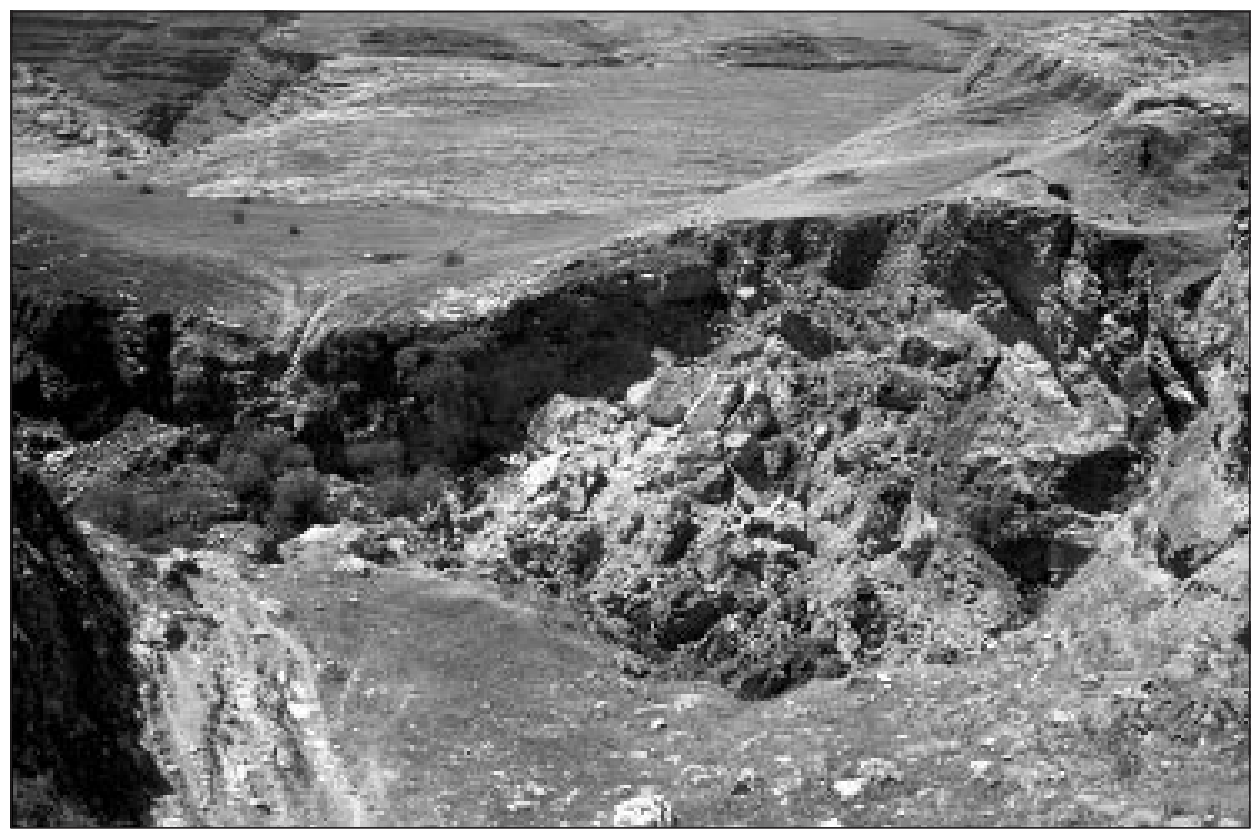

Fig. 9: A landslide covers the entrance of the cave in a collapse doline. 


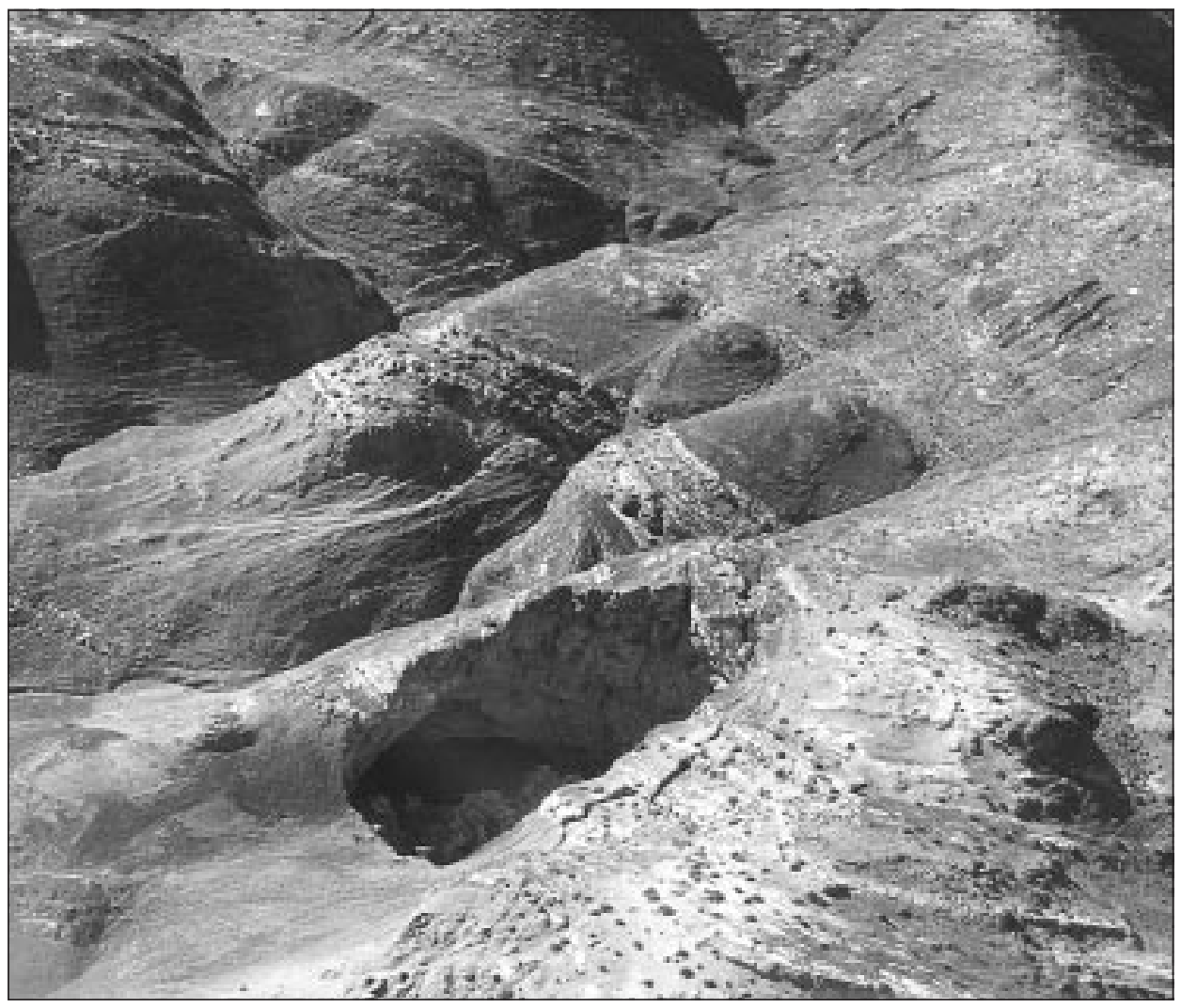

Fig. 10: A collapse doline.

products and only some minor water seepage was observed from some of the epigean karst landforms and at the river level. At the same time, the drainage system is well developed in the plateau surrounding the gorge: water courses are usually of a temporary nature and sometimes have cut very deep gullies.

Water precipitation on the Gachsaran products is bound to infiltrate in a higher percentage into sub horizontal to sub vertical swalow-holes and to flow within a suspended network of drainage. Part of this drainage flows up after a short circulation time, as indicated by the appearance of temporary springs immediately after periods of heavy meteoric precipitation.

As regards the depth of the drainage system, the data of the boreholes indicate that open cavities, allowing active karst circulation, are essentially restricted to the upper 30 to $40 \mathrm{~m}$. Below such depth some evidences were recognised of old karst features expressed by the occurrence of cavities infilling, but no openings were encountered.

As regards the outflow - direction, cavities controlling this flow are expected to develop preferentially along the bedding, as suggested by the configuration of the caves mapped at the contact between the Asmari and Gachsaran Formations. 

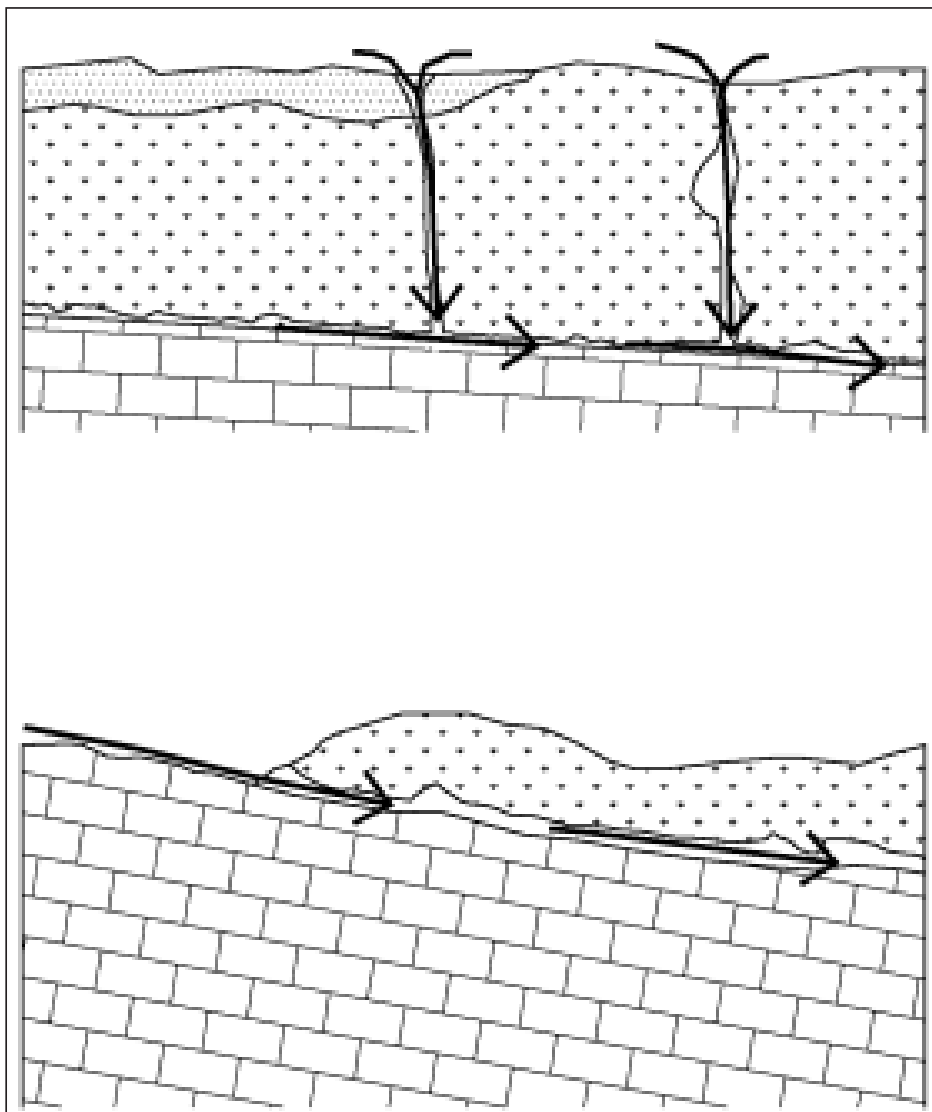

Fig. 11: Scheme of three types of epigean karst on the Zagros Mountains and of the most frequent epigean karst landforms in the Gachsaran Formation as a function of the localisation along the syncline axis or along a fold side: $A$ and $C$ along the axis, $B$ along the side.

A) Sinkholes and suffosion dolines (normally along the

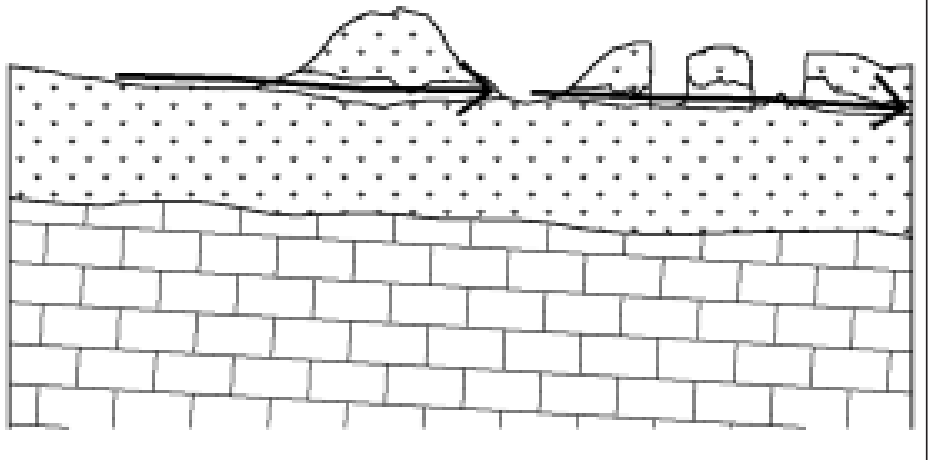
syncline axis).

B) Gently dipping galleries at the contact between limestone and gypsum following maximum dip.

C) Caves and collapse dolines (normally along the syncline axis). 


\section{REFERENCES}

Oberlander, T.M., 1986: Origin of drainage transverse to structures in orogens. Pp. 155-182. In Tectonic Geomorphology, Hack \& Morisawa Eds.

Bartolini, C. 1992: I fattori geologici delle forme del rilievo. 183 pp. Pitagora Editrice Bologna. 